\title{
Evaluation of skid resistance characteristics and measurement methods
}

\author{
Tadas Andriejauskas ${ }^{\mathrm{a}}$, Viktoras Vorobjovas ${ }^{\mathrm{a}}$, Valdas Mielonas ${ }^{\mathrm{b}}$ \\ ${ }^{a}$ Road Research Institute, Vilnius Gediminas Technical University, Linkmenu str. 28, LT-08217 Vilnius, Lithuania \\ ${ }^{b}$ Vilnius Gediminas Technical University, Sauletekio ave. 11, LT-10223 Vilnius, Lithuania
}

\begin{abstract}
Skid resistance is one of the major road pavement characteristics, which determines the friction between the road surface and vehicle tire. It is a crucial road surface characteristic to ensure sufficient road safety. The article gives a study of the parameters influencing skid resistance. Number of different methods and devices which are currently being used in practice to measure skid resistance both in the laboratory and in-situ in different countries were overviewed in this paper. As a result of the evaluation of skid resistance characteristics and measurement methods, the paper provides recommendations for skid resistance measurement suitability and applicability for Lithuanian road network.
\end{abstract}

Keywords: skid resistance; measurement methods; devices.

\section{Introduction}

Safe travel using road transport requires sufficient friction between vehicle tyres and road surface. One of the main factors influencing friction between the tyre and the road surface is roughness of road surface texture and is called skid resistance. Friction forces are necessary for the vehicle to safely accelerate, decelerate or change driving direction. It is known that low skid resistance is directly related to the increased accident risk [1], especially on wet roads. Performed research in some EU countries showed that use of road pavements with sufficiently high skid resistance could improve road safety by minimizing the vehicles sliding risk and at the same time accident risk and severity [2]. Accident rate can be significantly reduced by implementing proper measures to increase skid resistance in potentially dangerous locations (bridges, curves, intersections etc.).

Friction forces for particular combination of road surface and tyre are dependent on various factors such as tyre load and pressure, tread depth and shape, road surface characteristics, water or ice presence on pavement, driving speed and other. Factors influencing skid resistance can be divided into few groups: vehicle factors, road surface characteristics factors, road surface geometry factors, environmental condition factors and driving factors [3]. Skid resistance is not a constant due to many different influencing factors and it is the main reason that there is no absolute skid resistance measurement method in Europe. More than 12 different measurement devices are currently being used in practice and each of the devices use different measurement principles has different measurement speed and accuracy [4]. Presence of European market has created the need of harmonisation. Today there are international standards only on road surface macrotexture measurement by using sand patch method and skid resistance measurement by using dynamic measurement devices and pendulum tester SRT.

Methodologies for skid resistance measurements are different in European countries. In some countries there are required skid resistance coefficient measurements while in other countries main indicators are road surface macrotexture depth in correlation with skid resistance coefficient [5]. In Lithuania major requirement is specified for tyre and road friction coefficient dependently on the road significance. Macrotexture depth is an additional indicator. Many EU countries have developed national policies on skid resistance measurements. Some countries periodically measure skid resistance during road exploitation and compare the values with the design values while other countries have requirements of skid resistance values for new roads or reconstructed road sections [6]. It is important to identify the most effective and cost-efficient skid resistance measurement policy in Lithuania.

Corresponding author: Tadas Andriejauskas. E-mail address: tadas.andriejauskas@vgtu.lt

http://dx.doi.org/10.3846/enviro.2014.141

(C) 2014 The Authors. Published by VGTU Press. This is an open-access article distributed under the terms of the Creative Commons Attribution License, which permits unrestricted use, distribution, and reproduction in any medium, provided the original author and source are credited. 


\section{Skid resistance}

Skid resistance is road surface property which characterises road pavement roughness, impact on friction forces when the pavement is exposed to the wheel load. Friction is described as a movement resistance of two surfaces in at their contact location. Friction is expressed via friction coefficient which is a sum value of two acting forces, one is parallel to contact surface between two bodies and opposite to their movement direction (friction force), other acting force is perpendicular to the contact surface (normal force) [3].

When the vehicle accelerates, decelerates or manoeuvres, bigger than usual dynamic forces are being transmitted from wheels to the pavement and resulting a need of better friction to ensure safe driving. At normal conditions tyre/road contact surface area is sufficiently permanent, the friction is ensured, but when manoeuvring, appeared additional forces could exceed created friction and the tyres start to slide.

Knowing that tyre and road interaction is not fully researched field, it is accepted that friction is consists of 2 main impacts: adhesion and hysteresis [7], [8]. Adhesion occurs as an interaction of tyre tread and road surface and is dependent on surface area. It is stated that adhesion consists of many chemical/molecular processes when tyre rubber particles interact with surface and compose local bonds. Adhesion force is proportional to the strength of these bonds. Hysteresis occurs when tyre rubber is compressed (due to vehicle mass) into uneven road surface, soft rubber usually fit the surface profile. During slide, rubber deforms in road surface projection and sets back due to spaces between rises. Due to rubber viscoelastic properties, some kinetic energy disperses during process. Hysteresis forces are proportional to dispersed energy amount. Hysteresis relatively is not dependent on sliding speed, but very dependent on road surface macrotexture while adhesion is dependent on both sliding speed and road surface macrotexture [3], [7-9].

Skid resistance is very important road safety element, especially when the road surface is wet. It is determined that highest accident risk is when the road surface is wet on the horizontal curves where the skid resistance coefficient is 0.25 . Wet road surface accidents are more likely to occur on uphill or downhill (where slope is higher than 3\%) [2]. Other potentially dangerous driving conditions are decreased skid resistance due to heavy rain and poor road geometry combination or rapid skid resistance change due to polluted, deteriorated road surface or first snow.

It is calculated that accident risk due to slipped vehicle on road surfaces with skid resistance coefficients lower than 0.45 is 20 times higher than on the road surfaces where skid resistance coefficient is higher than 0.60 . If skid resistance coefficient is lower than 0.30 then accident risk is 300 times higher [2].

The most important factor for skid resistance is pavement macrotexture and because of it skid resistance increases when the driving speeds are high. In France it is determined, that accident risk rapidly increases for the road surfaces with mean texture depth lower than $0.5 \mathrm{~mm}[1]$.

Vehicle driving on the wet road surface generates spray and splash effect, what negatively affects the following or passing vehicle drivers' visibility. It is stated that spray is a potential danger to the road safety when the road surface is wet and the driving speed is higher than $60 \mathrm{~km} / \mathrm{h}[10]$.

Vehicle stopping distance is one of the crucial road safety influencing factors which is dependent on skid resistance. Increasing road surface skid resistance, vehicle stopping distance shortens and vehicle dynamic vibrations decreases (improved vehicle stability). Skid resistance as vehicle stopping distance factor is very relevant for road safety, especially on winter season (Fig. 1) [11].

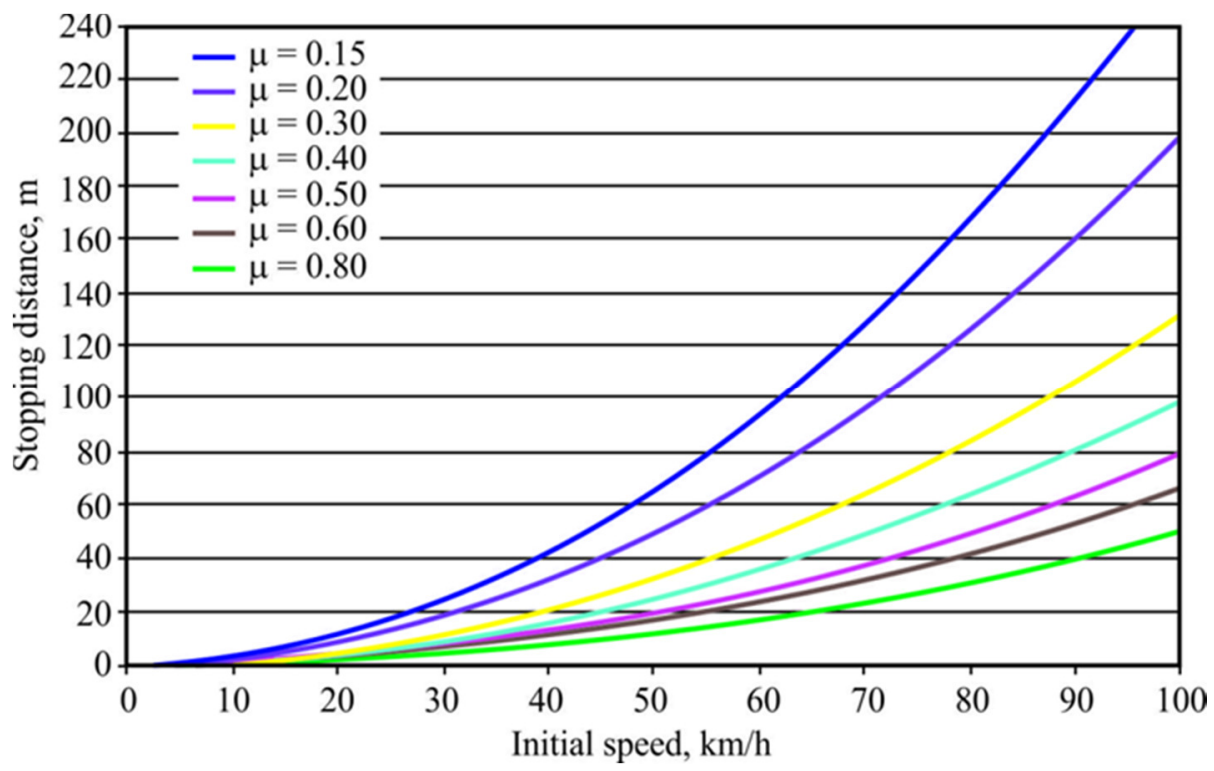

Fig. 1. Stopping distance relationship to skid resistance and driving [12]

Aquaplaning is also a dangerous phenomenon, which forms when the vehicle drives on wet road surface at particular speed [12], [13]. Driving on wet road surface, water gets between the tyres and the road, tyre front part fills in with water 
and the pressure raises the tyre. Water pressure is proportional to water density and two times higher than speed. When the tyre couldn't distribute water excess, the tyre raises up above the road surface and loses friction - vehicle starts to slide due to inertia, brakes don't work and vehicle becomes uncontrolled. Minimal water level for aquaplaning dependently on road surface, tyre and speed could be from 2.5 to $10 \mathrm{~mm}[12]$.

Main road pavement property influencing skid resistance is road surface texture [3], [9]. Skid resistance of wet road surface is decreasing while driving speed increases and skid resistance becomes dependent on pavement texture. However, pavement texture is dependent on designed asphalt an layer mixture, aggregate composition, pavement layer laying technologies. Rough microtexture leads to better skid resistance at lower speeds, rough macrotexture leads to better skid resistance at higher speeds.

Pavement materials has huge big influence on skid resistance, because better quality materials (they are more resistant to wear, crush and polishing) could ensure sufficient pavement skid resistance characteristics for a longer period. Aggregate shape influences mixture's smoothness. Aggregate particles with sharp edges are more preferable than polished particles due to better friction [14-15]. Aggregate size has impact on microtexture. Use of small and cleft aggregate particles results better skid resistance at lower speeds. However, use of too small particles could reduce skid resistance at higher speeds $[3,16]$. Newly laid pavements have good skid resistance characteristics and retain that for a few years. Later, due to traffic and climate impact the pavement starts to deteriorate and skid resistance starts to decrease.

Bitumen binder content [16] in asphalt mixture could also have a small impact on skid resistance. During hot days, bitumen could start bleeding and with bitumen could spill on the pavement also smallest mineral aggregate. Because of bleeding bitumen, road surface becomes slippery [3]. It is recommended to use polymer modified bitumen or higher viscosity bitumen.

Air void content of asphalt mixture don't have noticeable impact on skid resistance. However if air void content is lower than $2 \%$, it is likely that optimal microtexture and macrotexture composition will be lost. Texture loss has impact on faster pavement deterioration and skid resistance reduction [3].

Proper asphalt pavement installation could also have an impact on skid resistance, because if the asphalt mixture won't be manufactured or laid as it was designed, the optimal result wouldn't be achieved. It is important to ensure that there is no segregation in the mixture before laying [3]. When compacting laid asphalt it is important to ensure that the laid asphalt mixture is not compacted too much or too low.

One of the main and commonly occurring climate condition, which influence skid resistance, are precipitation and moisture on road surface.

\section{Measurement of skid resistance}

\subsection{Measurement principles}

Skid resistance is influenced by many various factors therefore many skid measurement devices was developed and currently are being used in practice. Some measurement devices are similar due to measurement principle, but the measurement method is different. Skid resistance measurement principles are divided in 3 groups [4, 18]:

- longitudinal friction measurement principle;

- transverse friction measurement principle;

- $\quad$ stationary of slow-moving friction measurement principle.

Longitudinal friction coefficient measurement principle is applied when the vehicle is travelling in a straight line and the brake pedal is pressed; breaking forces via braking system are transmitted to vehicle wheels. Angular speed of wheel decreases, kinetic vehicle rolling energy converts to thermal energy and the vehicle slows down. However, if the braking force is too big, vehicle wheel blocks and starts to slide on the road surface, in tyre and road contact surface generates friction forces which slow down the vehicle. Longitudinal friction coefficient measurement devices create this wheel blocking process by creating controlled sliding process. Slip ratio is used to assess and compare wheel and vehicle speeds. Slip ratio varies from 0 to 1: 0 - wheel speed is the same like vehicle speed, wheel rolls freely. 1 - wheel is fully blocked and slides on the road surface. Optimal slip ratio value varies from 0.15 to 0.20 . In this interval is ensured highest LFC and shortest vehicle stopping distance. When the slip ratio is higher, vehicle wheel starts to block and slide. Majority of longitudinal friction measurement devices measure using fixed slip ratio, which is determined automatically. But there are some devices which have variable slip ratio, increase friction force until the wheel starts to block. Devices with fixed slip ratio are better for monitoring purposes because they measure continuously while variable slip ratio devices could measure short length of road and are more suitable for research purposes [4], [18].

Transverse friction measurement principle is applied when the vehicle is travelling in a horizontal curve and the vehicle wheels are turned. Angle between vehicle and turned wheel direction is called slip angle $(\delta)$. Slip angle induce friction between tyre and road, which in turn generates a centripetal force opposing the centrifugal force exerted on the vehicle in the bend, allowing the vehicle to follow round the curve. When braking force increases the wheel starts to slip over the road surface. The sideway friction coefficient SFC varies with the tyre slip angle. Normally, the maximum SFC value occurs at a slip angle between $4^{\circ}$ and $7^{\circ}$ for a light vehicle, and between $6^{\circ}$ and $10^{\circ}$ for a truck. Skid resistance measurement devices commonly are operating using fixed slip angle. Devices with fixed slip are better for monitoring purposes because they 
measure continuously while variable slip ratio devices could measure short length of road and are more suitable for research purposes [4], [18].

Stationary or slow-moving measurement principle covers the devices, which are light, simple, portable and mostly used for laboratory or stationary testing. Static devices utilise rubber sliders to make contact with the road surface with a mechanism that initiates relative motion between the slider and the road. Two devices are used: pendulum arm which swings and with a rubber slider contacts the surface until friction forces slow down the slider; rotating head with sliders, which is lowered on to the road so that friction between the sliders and the road causes the head to slow down [4, 18]. Slowmoving devices are used to measure friction at very low speed or stationary, but these devices are good to measure friction for special purposes (e.g. road marking).

\subsection{Measurement devices}

There are a number of different skid resistance measurement methods and devices with different measurement speed, used tyre, wheel load, water film thickness. Measurement devices that are being used in practice in EU are shown in Table 1. Comparing these devices it was noticed that devices, which are operated by using LFC principle, have measurement speed, mobility advantages. Using these devices it is possible to measure LFC at different speeds $(40-140 \mathrm{~km} / \mathrm{h})$, devices are smaller and have better mobility, commonly completed as trailers. Howeve it is always required to have additional water metering system, which is mounted in accompanying vehicle. Transverse friction measurement devices perform measurement at medium speed, the devices are bigger and their operation costs are higher. However these devices are supplemented with large water tanks that allow long distance measurements.

Analysis of measurement methods and devices showed that all devices operate differently but some methods have advantages when the wheel is not completely blocked (testing tyre wear much slower) and with larger capacity water tanks what increases maximum measurement distance (e.g. GripTester, ROAR DK). Measurement devices with installed pavement macrotexture measurement equipment allow measurements of mean profile depth (MPD) for further comparisons and analysis of pavement surface condition and interrelationship between skid resistance and MPD. Stationary and slowmoving devices are slow and unproductive as measurements are performed mechanically. However these devices are useful when performing measurements in specific locations. Stationary and slow-moving devices are cheap, could be easily transported and operated.

In Lithuania tyre and pavement surface friction measurements are performed on newly laid asphalt layers as an acceptance tests 4-8 weeks after road opening. Tyre and road surface friction is determined by existing measurement standard (LST EN 13036-4:2012). Tyre and road friction measurements could also be measured by SRT-3 device.

Table 1. Skid resistance measurement devices [4], [18]

\begin{tabular}{|c|c|c|c|c|}
\hline Title & $\begin{array}{c}\text { Measurement } \\
\text { principle }\end{array}$ & Main parameters & Tyre and wheel load & Measurement device view \\
\hline ADHERA & $\begin{array}{l}\text { Longitudinal } \\
\text { friction coefficient } \\
\text { (LFC) }\end{array}$ & $\begin{array}{l}\text { Slip ratio: } 1,0 \text { or } 100 \% \\
\text { Water film thickness: } 1,0 \mathrm{~mm} \text {; } \\
\text { Measures macrotexture; } \\
\text { Measurement speed: } 40,60,90,120 \mathrm{~km} / \mathrm{h} \text {; } \\
\text { Measurement interval: } 20 \mathrm{~m} \text {. }\end{array}$ & $\begin{array}{l}\text { PIARC smooth profile tyre } \\
\text { 165R15 (180kPa); } \\
\text { Wheel load: } 2500 \mathrm{~N} \text {. }\end{array}$ & \\
\hline BV-11 & $\begin{array}{l}\text { Longitudinal } \\
\text { friction coefficient } \\
\text { (LFC) }\end{array}$ & $\begin{array}{l}\text { Slip ratio: } 0,17 \text { or } 17 \% \\
\text { Water film thickness: } 0,5-1,0 \mathrm{~mm} \\
\text { Measurement speed: } 70 \mathrm{~km} / \mathrm{h} \\
\text { Measurement interval: } 20 \mathrm{~m}\end{array}$ & $\begin{array}{l}\text { Trelleborg type T49 tyre } \\
(140 \mathrm{kPa}) \text {; } \\
\text { Wheel load: } 1000 \mathrm{~N} .\end{array}$ & \\
\hline GripTester & $\begin{array}{l}\text { Longitudinal } \\
\text { friction coefficient } \\
\text { (LFC) }\end{array}$ & $\begin{array}{l}\text { Slip ratio: } 0,15 \text { or } 15 \% \text {; } \\
\text { Water film thickness: } 0,5 \mathrm{~mm} \text {; } \\
\text { Measurement speed: } 5-100 \mathrm{~km} / \mathrm{h} \text {; } \\
\text { Measurement interval: } 10-20 \mathrm{~m} \text { or other. }\end{array}$ & $\begin{array}{l}254 \mathrm{~mm} \text { diameter smooth } \\
\text { profile ASTM-tyre } \\
(140 \mathrm{kPa}) ; \\
\text { Wheel load: } 250 \mathrm{~N} \text {. }\end{array}$ & \\
\hline RoadSTAR & $\begin{array}{l}\text { Longitudinal } \\
\text { friction coefficient } \\
\text { (LFC) }\end{array}$ & $\begin{array}{l}\text { Slip ratio: } 0.18 \text { or } 18 \% \text {; } \\
\text { Water film thickness: } 0.5 \mathrm{~mm} \text {; } \\
\text { Measures macrotexture; } \\
\text { Measurement speed: } 30,60 \mathrm{~km} / \mathrm{h} \text {; } \\
\text { Measurement interval: } 50 \mathrm{~m} \text {. }\end{array}$ & $\begin{array}{l}\text { PIARC tyre with tread; } \\
\text { Wheel load: } 3500 \mathrm{~N} \text {. }\end{array}$ & \\
\hline ROAR DK & $\begin{array}{l}\text { Longitudinal } \\
\text { friction coefficient } \\
\text { (LFC) }\end{array}$ & $\begin{array}{l}\text { Slip ratio: } 0.2 \text { or } 20 \% \text {; } \\
\text { Water film thickness: } 0.5 \mathrm{~mm} \text {; } \\
\text { Measures macrotexture; } \\
\text { Measurement speed: } 60,80 \mathrm{~km} / \mathrm{h} \text {; } \\
\text { Measurement interval: }>5 \mathrm{~m} \text {. }\end{array}$ & $\begin{array}{l}\text { ASTM } 1551 \text { tyre }(207 \mathrm{kPa}) \\
\text { Wheel load: } 1200 \mathrm{~N} \text {. }\end{array}$ & \\
\hline
\end{tabular}


T. Andriejauskas et al. / The $9^{\text {th }}$ Conference Environmental Engineering. Selected Papers, Article number: enviro.2014.141

\begin{tabular}{|c|c|c|c|c|}
\hline Title & $\begin{array}{c}\text { Measurement } \\
\text { principle }\end{array}$ & Main parameters & Tyre and wheel load & Measurement device view \\
\hline ROAR NL & $\begin{array}{l}\text { Longitudinal } \\
\text { friction coefficient } \\
\text { (LFC) }\end{array}$ & $\begin{array}{l}\text { Slip ratio: } 0.86 \text { or } 86 \% \text {; } \\
\text { Water film thickness: } 0.5 \mathrm{~mm} \text {; } \\
\text { Measures macrotexture; } \\
\text { Measurement speed: } 50,70 \mathrm{~km} / \mathrm{h} \text {; } \\
\text { Measurement interval: } 5-100 \mathrm{~m} \text {. }\end{array}$ & $\begin{array}{l}\text { ASTM } 1551 \text { tyre } \\
(200 \mathrm{kPa}) ; \\
\text { Wheel load: } 1200 \mathrm{~N} \text {. }\end{array}$ & 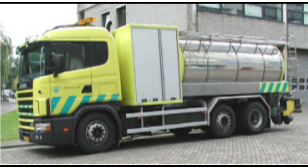 \\
\hline $\begin{array}{l}\text { RWS NL } \\
\text { Skid } \\
\text { Resistance } \\
\text { Trailer }\end{array}$ & $\begin{array}{l}\text { Longitudinal } \\
\text { friction coefficient } \\
\text { (LFC) }\end{array}$ & $\begin{array}{l}\text { Slip ratio: } 0.86 \text { or } 86 \% \text {; } \\
\text { Water film thickness: } 0.5 \mathrm{~mm} \text {; } \\
\text { Measurement speed: } 50,70 \mathrm{~km} / \mathrm{h} \text {; } \\
\text { Measurement interval: } 5-100 \mathrm{~m} \text {. }\end{array}$ & $\begin{array}{l}\text { PIARC smooth profile tyre } \\
\text { 165R15 (200kPa); } \\
\text { Wheel load: } 1962 \mathrm{~N} .\end{array}$ & \\
\hline SCRIM & $\begin{array}{l}\text { Sideway friction } \\
\text { coefficient (SFC) }\end{array}$ & $\begin{array}{l}\text { Slip angle: } 20^{\circ} \text {; } \\
\text { Water film thickness: } 0.5 \mathrm{~mm} \text {; } \\
\text { Measures macrotexture; } \\
\text { Measurement speed: } 50 \mathrm{~km} / \mathrm{h} \text {; } \\
\text { Measurement interval: }>10 \mathrm{~m} \text {. }\end{array}$ & $\begin{array}{l}\text { Avon SCRIM smooth } \\
\text { profile tyre } 76 / 508 \\
\text { (350kPa); } \\
\text { Wheel load: } 1960 \mathrm{~N}\end{array}$ & \\
\hline $\begin{array}{l}\text { Skiddometer } \\
\text { BV-8 }\end{array}$ & $\begin{array}{l}\text { Longitudinal } \\
\text { friction coefficient } \\
\text { (LFC) }\end{array}$ & $\begin{array}{l}\text { Slip ratio: } 100 \% \text { or } 14 \% \text {; } \\
\text { Water film thickness: } 0.5 \mathrm{~mm} \text {; } \\
\text { Measurement speed: } 40,60,80 \mathrm{~km} / \mathrm{h} \text {; } \\
\text { Measurement interval: } 30-50 \mathrm{~m} \text {. }\end{array}$ & $\begin{array}{l}\text { AIPCR tyre with } \\
\text { longitudinal tread } 165 \mathrm{R} 15 \text {; } \\
\text { Wheel load: } 3500 \mathrm{~N} \text {. }\end{array}$ & \\
\hline SKM & $\begin{array}{l}\text { Sideway friction } \\
\text { coefficient (SFC) }\end{array}$ & $\begin{array}{l}\text { Slip angle: } 20^{\circ} \text {; } \\
\text { Water film thickness: } 0,5 \mathrm{~mm} \text {; } \\
\text { Measurement speed: } 50 \mathrm{~km} / \mathrm{h} \text {; } \\
\text { Measurement interval: } 100 \mathrm{~m} \text { or other. }\end{array}$ & $\begin{array}{l}\text { Smooth profile tyre; } \\
\text { Wheel load: } 1960 \mathrm{~N} \text {. }\end{array}$ & \\
\hline SRM & $\begin{array}{l}\text { Longitudinal } \\
\text { friction coefficient } \\
\text { (LFC) }\end{array}$ & $\begin{array}{l}\text { Slip ratio: } 15 \% \text { or } 100 \% \text {; } \\
\text { Water film thickness: } 0.5 \mathrm{~mm} \text {; } \\
\text { Measurement speed: } 40,60,80 \mathrm{~km} / \mathrm{h} \text {; } \\
\text { Measurement interval: } 20 \mathrm{~m} \text { or other. }\end{array}$ & $\begin{array}{l}\text { AIPCR tyre with } \\
\text { longitudinal tread } 165 \mathrm{R} 15 \text {; } \\
\text { Wheel load: } 3500 \mathrm{~N} \text {. }\end{array}$ & \\
\hline TRT & $\begin{array}{l}\text { Longitudinal } \\
\text { friction coefficient } \\
\text { (LFC) }\end{array}$ & $\begin{array}{l}\text { Slip ratio: } 25 \% \text {; } \\
\text { Water film thickness: } 0.5 \mathrm{~mm} \text {; } \\
\text { Measurement speed: } 40-140 \mathrm{~km} / \mathrm{h} \text {; } \\
\text { Measurement interval: } 20 \mathrm{~m} \text { or other. }\end{array}$ & $\begin{array}{l}\text { Smooth profile ASTM- } \\
\text { tyre; } \\
\text { Wheel load: } 1000 \mathrm{~N} \text {. }\end{array}$ & \\
\hline SRT-3 & $\begin{array}{l}\text { Longitudinal } \\
\text { friction coefficient } \\
\text { (LFC) }\end{array}$ & $\begin{array}{l}\text { Slip ratio: } 100 \% \text {; } \\
\text { Water film thickness: } 0.5 \mathrm{~mm} \text {; } \\
\text { Measurement speed: } 60 \mathrm{~km} / \mathrm{h}\end{array}$ & Tyre with tread $(200 \mathrm{kPa})$. & \\
\hline IMAG & $\begin{array}{l}\text { Longitudinal } \\
\text { friction coefficient } \\
\text { (LFC) }\end{array}$ & $\begin{array}{l}\text { Slip ratio: } 100 \% \text {; } \\
\text { Water film thickness: } 1.0 \mathrm{~mm} \text {; } \\
\text { Measurement speed: } 65 \mathrm{~km} / \mathrm{h} \text {; }\end{array}$ & $\begin{array}{l}\text { PIARC smooth profile tyre; } \\
\text { Wheel load: } 1500 \mathrm{~N} \text {. }\end{array}$ & \\
\hline $\begin{array}{l}\text { DFT } \\
\text { Dynamic } \\
\text { Friction } \\
\text { Tester }\end{array}$ & Rotating friction & For stationary measurements & - & \\
\hline $\begin{array}{l}\text { SRT } \\
\text { Pendulum }\end{array}$ & Pendulum test & For stationary measurements & - & is \\
\hline
\end{tabular}


T. Andriejauskas et al. / The $9^{\text {th }}$ Conference Environmental Engineering. Selected Papers, Article number: enviro.2014.141

\begin{tabular}{|l|l|l|l|l|}
\hline \multicolumn{1}{|c|}{ Title } & \multicolumn{1}{c|}{$\begin{array}{c}\text { Measurement } \\
\text { principle }\end{array}$} & \multicolumn{1}{|c|}{ Main parameters } & Tyre and wheel load & Measurement device view \\
\hline T2GO & $\begin{array}{l}\text { Slow-moving } \\
\text { measurement; } \\
\text { Longitudinal } \\
\text { friction coefficient } \\
\text { (LFC) }\end{array}$ & $\begin{array}{l}\text { Slip ratio: 20\%; } \\
\text { Used for pedestrian/bicycle paths, road } \\
\text { marking }\end{array}$ & Two $75 \mathrm{~mm}$ width tyres. & \\
\hline $\begin{array}{l}\text { VTI Portable } \\
\text { Friction }\end{array}$ & $\begin{array}{l}\text { Slow-moving } \\
\text { Teasurement; } \\
\text { Longitudinal } \\
\text { friction coefficient } \\
\text { (LFC) }\end{array}$ & Used for pedestrian/bicycle paths & - & \\
\hline
\end{tabular}

\subsection{Measurement policy}

Most of EU countries have national skid resistance measurement policies, which cover measurement methodologies, purposes, devices, thresholds, frequency, measurement extent and measured roads. In EU skid resistance is commonly measured for local investigations, for acceptance tests and as a research tool. Skid resistance devices also are used for warranty tests, to support skid resistance standards or as a part of condition index [5].

Important factor in skid resistance measurement policy is threshold levels, which are the values that are compared to the skid resistance characteristic values and could trigger some kind of action when the skid resistance falls to the threshold level. Threshold could be fixed or "warning" type. Fixed threshold is the value of skid resistance, and when it falls below this value, and then action to improve the surface must be taken. Warning thresholds are good option because if skid resistance falls below this level it provides a warning that accident risk may be increasing and therefore an investigation should be made to assess whether treatment is necessary or appropriate. In EU practice threshold levels are mostly based on statistics, accident analysis and theoretical calculations (accident risk calculations). For motorways thresholds mainly have been determined on statistics and accident risk, on primary roads accident risk and statistics. To set thresholds based on accident analysis it is very important for country to have good accident records to combine them with special skid resistance survey. For the countries, that are introducing skid resistance policy, good option is to set thresholds based on another country which has networks with similar characteristics. The policy must also indicate what action will be taken when the threshold is not met. It depends on the type of threshold that has been set. A fixed threshold would require immediate action: to improve skid resistance or build warning signs to alert drivers to potential risks until the appropriate measures have been carried out. Warning threshold levels may not require immediate action to increase skid resistance but would nevertheless require carrying out an investigation to determine whether treatment might be required [5], [19].

Many EU countries mostly apply measurements for secondary roads, primary roads and motorways. Measurement frequency also varies due to the use of different devices, different size of road network and different allocated funds. Some countries measure twice a year while other countries measure annually, every $2^{\text {nd }}, 3^{\text {rd }}, 4^{\text {th }}$ or $5^{\text {th }}$ year. Regarding measurement frequency due to significance of roads it is observed that in most of the EU countries, skid resistance measurements in motorways are performed annually, in primary roads annually or every $2^{\text {nd }}$ year and in secondary roads every $2^{\text {nd }}$ year [5-6]. Skid resistance measurements are quite expensive and the strategy of measurement frequency should be selected in accordance to measurement costs and measurement objectives. Surveying whole network annually is the most expensive option, but allows to measure skid resistance when at its lowest during the year and compare data between the years. Rarer measurements reduce surveying and processing costs, but increase the risk of not detecting sites which fall below thresholds.

Mostly, measurements for routine monitoring are made between spring and autumn. In winter, weather conditions and minimum temperature limits for the devices do not allow correct measurements. However in some countries, where snow and ice on roads is a common condition for a significant period of the year, routine monitoring is done in winter, even on icy roads [5-6].

In many EU countries both directions of motorways are measured and on primary roads one direction only. Skid resistance mostly is monitored in one lane. Special attention is linked to the measurement of potentially dangerous locations such as ramps, intersections [5].

Acceptance tests could be carried out: only before road opening, only after road opening; before and after road opening. Most common application of acceptance tests is only after road opening as it seems the most economically efficient.

\section{Recommendations for skid resistance measurements in Lithuania}

In accordance to skid resistance measurement policies and practice in different EU countries, it is recommended to identify main skid resistance policy development directions for Lithuanian road network and to start implementation of these guidelines. 
The most popular and commonly used skid resistance measurement devices in European market are Pendulum SRT, SCRIM and Grip Tester. For acceptance and self-control tests of skid resistance values (especially when the road sections are short and use automated measurement devices is economically inefficient) it is recommended to continue using Pendulum SRT devices, but for skid resistance monitoring in Lithuanian road network it is recommended to use high-speed automated measurement devices. Regarding the length of Lithuanian road network and preliminary costs of skid resistance measurements, measurement devices and their exploitation, longitudinal friction measurement devices are more preferable due to their prices and simplicity to use. It is important to note, that SRT-3 device (currently used in Lithuania) operation based on blocked wheel principle and not on fixed slip ratio value. For this reason, testing tyre wear out faster and it is required to change test tyre often in regards to accumulate accurate measurement results. One of alternative devices is GripTester, which uses smooth profile test tyre, is sufficiently mobile and possible to perform measurements at high speeds (up to $100 \mathrm{~km} / \mathrm{h}$ ). Test tyre is not blocked so it can be used much longer. Transverse friction measurement devices such as SCRIM are also suitable for Lithuania because of these devices advantages to continuously measure long road sections and also assess road surface macrotexture. However these devices are more expensive and their suitability for Lithuanian road network has to be substantiated by detailed and comparable economic efficiency analysis.

Skid resistance measurements in recommended to be performed periodically in whole Lithuanian road network not only to collect data about potentially dangerous locations because of decreased pavement skid resistance but also to use collected data about skid resistance value changes for pavement management systems.

Lithuanian technical regulations oblige to measure pavement skid resistance only after road repair or reconstruction works and after building new road. Since there are no comparable skid resistance measurement studies (measurements aren't being performed for the same road section several years in a row) except the measurements for newly laid or reconstructed roads and in accordance to EU countries practice it is recommended to perform skid resistance measurement in Lithuanian national significance main roads and potentially dangerous road sections - annually, in national and regional roads - every $3^{\text {rd }}$ year. In regional roads measurements should be performed in a road sections with high accident rate.

In existing building recommendations R 35-01 "Asphalt and gravel road pavements" it is determined that friction coefficient for newly laid asphalt layers in main roads must be not lower than 0.40 , in national and regional roads -0.35 . Minimal friction values in operated roads could be 0.30 during summer season. To improve traffic quality and to reduce accident risk, there also should be defined skid resistance thresholds for potentially dangerous locations. Requirements for skid resistance in intersections, roundabouts, small radius curves, uphill/downhill and on bridges should be tightened. For skid resistance threshold calculations recommended to be based on accident risk analysis and accident statistics. Thresholds should be "warning" type - if measured skid resistance values are over the threshold, the location should be investigated and appropriate solution proposed (it could be not just improving skid resistance, but also road reconstruction etc.)

\section{Conclusions}

1. Skid resistance is one of the substantial factors which ensure safe travelling on automobile roads. Because of poor road safety situation in Lithuania (comparing with EU average), old vehicle fleet and many vehicles that are driven with old or outworn tyres there is a need to improve safety situation. Road pavements with high and long-lasting skid resistance could be a solution.

2. Developing pavements with high skid resistance it is essential to develop harmoniously from tyre and road contact noise and rolling resistance point of view. All these characteristics are important and related with road surface texture.

3. Amongst all analysed friction measurement methods and devices, one of the most effective and suitable skid resistance measurement devices for Lithuanian road network could be GripTester which is based on longitudinal friction measurement principle. Advantages of this device is fast measuring speed, not very expensive and simple operation

4. It is important to develop Lithuanian skid resistance policy covering skid resistance measurements not only for acceptance tests but also for skid resistance routine monitoring in whole Lithuanian road network and include skid resistance measurement data into pavement management systems.

5. Because there is no periodically skid resistance measurement experience in Lithuania, the thresholds should be determined using accident statistical data and theoretical calculations. It is also recommended to define higher skid resistance thresholds for potentially dangerous locations.

\section{References}

[1] Wang, C; Quddus, M.; Ison, S. 2013. The effect of traffic and road characteristics on road safety: A review and future research direction, Safety Science 57: 264-275. http://dx.doi.org/10.1016/j.ssci.2013.02.012

[2] Gothie, M. 1996 Relationship between Surface Characteristics and Accidents, in Proceedings of 3rd International Symposium on Pavement Surface Characteristics, 271-281.

[3] Kane, M.; Scharnigg, K. 2009. Report on different parameters influencing skid resistance, rolling resistance and noise emissions. TYROSAFE project deliverable D10,95 p.

[4] Descornet, G.; Schmidt, B.; Boulet, M.; Gothie, M.; Do, M-T.; Fafie, J.; Alonso, M.; Roe, P.; Forest, R.; Viner, H. 2006. Harmonization of European Routine and research Measuring Equipment for Skid Resistance. HERMES final report. $161 \mathrm{p}$.

[5] Anfosso-Ledee, F.; Nitsche, P.; Schwalbe, G.; Spielhofer, R.; Saleh, P. 2009. Report on policies and standards concerning skid resistance, rolling resistance and noise emissions. TYROSAFE project deliverable D06, $378 \mathrm{p}$. 
[6] Anfosso-Lédée, F.; Kokot, D.; Roe, P.; Schwalbe, G.; Spielhofer, R. 2009. Recommendations for future harmonised EU policies on skid resistance, rolling resistance and noise emissions. TYROSAFE project deliverable D08, $70 \mathrm{p}$.

[7] Bachmann, T.; Bernhard, M.; Endres, J. 1997. Auswertung von Reibwertmessungen zur Überprüfung und Beurteilung des Bewertungshintergrundes für Griffigkeitsfestlegungen im Straßenentwurf, TU Darmstadt, Darmstadt.

[8] SKIDSAFE [online]. 2014. SKIDSAFE (Enhanced driver safety due to improved skid resistance) Project [cited 18 January 2014] . Available from Internet: http://www.skidsafe.org/index $1 . h$ tml

[9] Cesbron, J.; Anfosso-Ledee F.; Yin, H.P.; Duhamel, D.; Le Houdec, D. 2008.Influence of Road Texture on Tyre/Road Contact in Static Conditions, Road Materials and Pavement Design 9(4): 689-710. http://dx. doi.org/10.1080/14680629.2008.9690145

[10] Al-Masaeid, H. R. 1997. Impact of pavement condition on rural road accidents. Canadian Journal of Civil Engineering 24(4): 523-531. http://dx.doi.org/10.1139/197-009

[11] Haavasoja, T.; Pilli-Sihvola, Y. 2010. Friction as a measure of slippery road surfaces, in Proceedings of the $15^{\text {th }}$ SIRWEC Conference, Quebec City, Canada.

[12] Browne, A. 1972. Dynamic hydroplaning of pneumatic tires, Wear 20(I): 1-28. http://dx.doi.org/10.1016/0043-1648(72)90284-0

[13] Crisman, B.; Roberti, R. 2012. Tire wet-pavement traction management for safer roads, Social and Behavioral Sciences 53: 1055-1068. http://dx.doi.org/10.1016/j.sbspro.2012.09.955

[14] Cafiso, S.; Taormina, S. 2007. Texture analysis of aggregates for wearing courses in asphalt pavements, International Journal of Pavement Engineering 8(1): 45-54. http://dx.doi.org/10.1080/10298430600898307

[15] Kokkalis, A. G.; Panagouli, O. K. 1998. Fractal Evaluation of Pavement Skid Resistance Variations[I] Surface Wetting. Chaos, Solitons \& Fractals 9(11): 1875-1890. http://dx.doi.org/10.1016/S0960-0779(97)00138-0

[16] Asi, I. M. 2005. Evaluating skid resistance of different asphalt concrete mixes, Building and Environment 42: 325-329. http://dx.doi.org/10.1016/j.buildenv.2005.08.020

[17] Kane, M.; Zhao, D.; Do, M-T.; Chailleux, E.; De-Lalarrard, F. 2010. Exploring the Ageing Effect of Binder on Skid Resistance Evolution of Asphalt Pavement, Road Materials and Pavement Design 11: 543-557. http://dx.doi.org/10.1080/14680629.2010.9690346

[18] Do, M-T.; Roe, P. 2008. Report on state-of-the-art of test methods.TYROSAFE project deliverable D04, 89 p.

[19] Papageorgiou, G. P.; Mouratidis, A. 2013. A mathematical approach to define threshold values of pavement characteristics, in Structure and Infrastructure Engineering: Maintenance, Management, Life-Cycle Design and Performance. http://dx.doi.org/10.1080/15732479.2012.757331 